\title{
Effect of Cooperative Learning on Achievement of Students in General Science at Secondary Level
}

\author{
Qaisara Parveen \\ Assistant Professor \\ Division of Continuing Education Home Economics \& Women Development \\ University of Arid Agriculture, Rawalpindi, Pakistan \\ E-mail: qaisarach@yahoo.com \\ Sadia Batool \\ Ph.D Scholar \\ International Islamic University, Islamabad, Pakistan
}

Received: October 24, 2011 Accepted: November 2, $2011 \quad$ Published: April 1, 2012

doi:10.5539/ies.v5n2p154

URL: http://dx.doi.org/10.5539/ies.v5n2p154

\begin{abstract}
The aim of the study was to explore the effects of cooperative learning on General Science achievement among $9^{\text {th }}$ class students. Based upon previous research literature it was hypothesized that significant difference existed between the mean posttest scores of General Science achievement of experimental group and control group. The pretest posttest control group design was chosen for the experiment. The study sample consisted of 36 students of $9^{\text {th }}$ class who were equally distributed among experimental group and control group, matched on the basic of their annual examination at general science scores. The dependent variable of General Science achievement was measured through self-constructed 30-item achievement test used as a pretest as well as a posttest. The experiment group was taught through cooperative learning while control group was taught through traditional teaching. The material was used such as lesson plans, worksheets and quizzes, designed to implement cooperative learning methodology. The data were analyzed through mean, standard deviation and t-test and .05 was the selected level of significance. The main result of the study was that cooperative learning method is superior to traditional method in general science achievement of $9^{\text {th }}$ grade students.
\end{abstract}

Keywords: Cooperative learning, Academic achievement, General science

\section{Introduction}

Teaching in not a mechanical process, it is an intricate, exciting and challenging job. Teaching is an art and truly fine teacher is an artist. Teaching requires a high degree of flexibility, adaptability and nimbleness of mint that goes far beyond the mechanical application of step by step procedure (Shamim, 1999). In fact group work means several students working together and working together does not necessarily involve cooperation. Cooperative learning in an arrangement in which students work in mixed ability groups and are awarded on the basis of the success of the group (Woolfolk, 2004).

In cooperative learning classrooms students work in small group and rewards are based on the entire group performance, this is a small group method or technique (Sprinthall and Sprinthall, 2000). Cooperative learning activities are carefully structured learning activities in which students are held accountable for their contribution, participation and learning, they are also provided incentives to work as team in teaching others and learning from others (Slavin, 2000). Cooperative learning is an instructional strategy in which students engage in activities that promote collaboration and teamwork. Individual achievement is sometimes over looked in favor of group accomplishment (Johnson et al, 1987).

\section{Review of Related Literature}

Slavin and others (1991) carried out research on STAD a type of cooperative learning. They used experimental design on students in their school. The sample of study was 139 students and the subject was social studies. The results of the study were positive and significant. Arbab (2003) investigated the effects of cooperative learning on 
the achievement of $6^{\text {th }}$ class students in the subject of English. The sample comprised 36 students of $6^{\text {th }}$ class equally placed in experimental group and control group on the basic of score obtained in the subject of English in previous annual examination in this experiment of four weeks, "Cooperative learning resulted in higher achievement as compared to routine method of teaching in English."

Parveen and others (2010) investigated the effect of cooperative learning on academic achievement of $8^{\text {th }}$ grade students in the subject of social studies. The pre test post control group design was chosen for experiment. The study sample consisted of 35 students who were distributed among experimental group $(\mathrm{N}=18)$ and control group $(\mathrm{N}=17)$. The result of the study did not confirm research hypothesis. Cooperative learning was not found to be a better instructional strategy than routine method of instruction.

Slavin (1995) examined ninety nine studies that fasted for four or more weeks and that used a variety of the ninety nine experimental method (64\%) of the ninety nine experimental control Comparison favored cooperative learning only five 5\% significantly favored the control group overall students in cooperative learning group scored about one fourth of a standard deviation higher on achievement tests than did students taught conventionally.

In Pakistan, there does not seem to be much research on cooperative learning. Therefore, it is prime need to conduct studies so as to explore the usefulness of various kinds of cooperative learning for different subject areas at different levels of education. In fact secondary level is the most critical level of education requiring modern methods to improve its quality.

\section{The objectives of the study were:}

- To teach the experimental group through cooperative learning and control group through traditional teaching without cooperative learning

- To measure the General Science achievement of experimental and control group after the experiment

- To compare the performance of the experimental group with control group

\section{Hypotheses of the study:}

The following null hypotheses were tested in this study:

1) There is no significant difference between mean pretest scores and mean posttest scores of the experimental group.

2) There is no significant difference between mean pretest scores and mean posttest scores of the control group.

3) There is no significant difference between the mean achievement scores of the control group on posttest and mean achievement scores of the experimental group on posttest.

Random sampling technique was used to select the sample of the study. Female students of class $9^{\text {th }}$ in Govt. High School Dhok Ratta Rawalpindi were taken as sample. Sample size was 36 students. Majority of students were the children of middle class background.

\section{Instrument}

In order to measure the General Science achievement of the sample students before and after the study, an achievement test was especially designed. It was consisted of 30 items. Test items included matching and multiple choice. Thirty percent items were related to the previous knowledge of the students in the subject of General Science. However $70 \%$ items were related to the content to be taught during the study. The total marks allocated to the test were 30 and time duration was 30 minutes. The test after its construction was shown to the subject specialist for its content validation and expert opinion for its improvement. After the approval with certain modification like change of place of right answer from its earlier position, the instrument was used for measurement purpose.

\section{Material}

The material used in the study consisted of five lesson plans, five work sheets and five quizzes. The material as mentioned above was prepared in the light of literature available on cooperation learning.

\section{Design}

The design of the study was pretest posttest control group design, which is true experiment design. This design was selected because it controls many variables inflecting its external and internal validity. The design is represented schematically as
$\begin{array}{llll}\mathrm{RE} & \mathrm{O}_{1} & \mathrm{~T} & \mathrm{O}_{3}\end{array}$
$\begin{array}{llll}\mathrm{RC} & \mathrm{O}_{2} & - & \mathrm{O}_{4}\end{array}$ 
As the above diagram shows, the sample was randomly divided into experimental and control groups, then provided treatment and post tested.

\section{Procedure}

The following procedure was adopted for experimentation and data collection:

In order to obtain the willingness, Headmistress of the school was contacted. The Headmistress directed the subject teacher to inform the investigator about the content in General Science to be taught during the next fortnight, which was made available for development of lesson plans. On the same day, the marks obtained by the sample students in there recently held examination was obtained from the school office. The pretest was administered to the sample during their class period of General Science. The test was unclear and student did not know about it before hand. Before the test administration the students were told that the test was being taken to see how far they understood the content of General Science. They were ensured that the test results were nothing to do with their promotion or school examination. The pretest results were preserved for data analysis from the total strength of sample students who were 36 in numbers, 18 students were assigned control group while the same strength of students was assigned to experimental group. Both groups were almost equal in their understanding of General Science; they were randomly named as experimental group and control group. The experiment was started from the following day onwards. The experimental group was taught in the actual classroom, especially arranged for them. Experimental group was taught through cooperative learning by researcher and the control group was taught by General Science teacher of the same class. After delivering the first lesson, the experimental group of 18 students divided in to six cooperative groups with each group consisting of three members.

The grouping was done on the basis of the entries of the attendance register. The first three students were assigned to one group and so on. The next day researcher formulated two copies of work sheet which were given to each group and students were instructed and encouraged to help each other and learn from each other. In completing the work sheet after engaging the students, each group was given the answer sheet so that they know whether they answered the question on the work sheet correctly. The completed worksheets along with answer sheets were collected from groups at the end of period. A 10 items quiz administered to the experimental group on the following day during the General Science period. The subjects were individually tested which was insured by seating them at a distance from one other. The papers were scored the same day and result was announced in the class before starting the lesson. The subjects were informed about their individual marks as well as the group marks. The group scores were calculated by converting obtained marks of each student into percentages. The process of calculating the group score was done strictly according to the scheme given by Slavin (1995). The same procedure as given above was used for the remaining lessons till the completion of experimental treatment. On the last day the posttest was administered to both experimental group and control group in the same room and the same time where pretest was held, the posttest was scored in order to obtain the posttest scores of each subject of experimental group and control group.

\section{Analysis and Discussion}

The table 1 mentioned in references indicates, the General Science scores of experimental group and control group in the annual examination were 53.0 and 50.3 respectively. The spread of score for the above groups was 19.2 and 13.7. Though the subjects were matched on the General Science marks obtained by them in the annual examination, however, they were equivalent in their previous performance in General Science because t-value (0.6) was not significant at .05 level.

Table 2 in mentioned in references indicates, the mean pretest score of experimental group was 11.89, whereas the mean pretest scores of control group was 11.78. Both the groups were found to be almost equal on their pretest performance with no significant difference $(\mathrm{t}=1.00)$ in terms of mean and spread of scores.

Table No.3 mentioned in references shows that mean posttest scores of experimental group was 27.3, whereas the mean posttest scores of control group was 21.1. The difference between the posttest means scores was found to be the spread of scores around the mean of experimental group was scattered around the mean posttest score to the extent of 2.87. The dispersion of posttest scores of both the groups was thus almost equal.

Table No.4 mentioned in references shows that means pretest score of experimental group was 11.8 and mean posttest score of experimental group was 27.3. There was an improvement in the overall performance of experimental group as the result of treatment. However, spread of mean posttest score increased only a bit.

Table No.5 shows that there was an improvement in the overall performance of control group as a result of annual teaching. However, the spread of posttest scores increased, thereby inflicting the improvement in performance.

Table No.6 reveals that the $t$ value is 51.7. The value is significant at .05 level. The null hypothesis No. I is therefore rejected. 
Table No.7 mentioned in references states that the $t$ value is 4.8 . The value is significance at 0.5 levels. The null hypothesis No.2 is therefore rejected.

Table 8 shown in references indicates that though the means posttest score of experimental group was higher than mean posttest scores of control group, the calculated $t$ value (8.07) was significant at .05 level because it was much higher than the critical value of 2.03 the null hypothesis No.3 is therefore rejected. It was therefore calculated that both the groups differed in their posttest performance.

\section{Conclusions}

The null hypothesis No.1 was rejected. It was, therefore concluded that the academic performance of experimental group before treatment differed from its academic performance after the treatment.

The null hypothesis No.2 was rejected. It was, therefore, concluded that the academic performance of control groups (taught through routine method) showed better after teaching.

The null hypothesis No.1 was rejected. It was, therefore concluded that the academic performance of the student taught through routine method differed in their academic performance from the group of students taught through cooperative learning group was better than the group taught without cooperative learning.

To sum up, it can generally be concluded in view of conclusion No.3 that cooperative in the teaching of General Science to 9th Class students.

\section{Recommendations}

On the basis of above conclusions, the following recommendations are drawn for further research.

Thought it was assumed that the experimental group and control groups were almost equal on all the factors except the independent variable, yet there were visible differences in the teachers, competence, teaching environment and teacher qualification and experience. Though differences could not be perfectly eliminated, yet these could be reduced as far as possible.

In the present study, only female subjects were used as study sample. It is recommended that similar studies be carried out on male subjects to generalize the results about effects of cooperative learning on student's social studies achievement. Administrative control of government and non-governmental organizations. This step will also help generalizing the result about effectiveness of cooperative learning to different population.

Previous research indicates that cooperative learning results in cognitive and affective growth of students. Therefore, in addition to investigate the effective of cooperative learning on academic performance, effectiveness of cooperative learning on students' self-esteem, social skills and academic motivation may also be studied.

In the present study the model of cooperative learning was used on one school subject, namely General Science. This model may also be tried out on other school subjects at elementary and secondary level and also on different type of students like slow learners and special students.

\section{References}

Arbab, S. (2003). Effects of Cooperative Learning on the Achievement of 6th Class Students in the Subject of English (unpublished M.A dissertation). Rawalpindi: PAF College of Education for Women

Gay, L. R. (2000). Educational Research Competencies for Analysis and Application. (Fifth Edition). Florida: Florida International University

Johnson, D.W.et al. (1987). Circles of Learning: Cooperation in the Classroom. Alexandria: Addison-Wesley

Parveen, S. (2010). Effect of Cooperative Learning on Academic Achievement of 8th Grade Students in the Subject of Social Studies. International Journal of Academic Research, Vol. 3, No1, pp. 950-955.

Shamim, A. (1999). Evaluation of Pakistan Studies Text book for Secondary Level. Islamabad: National Book Foundation

Slavin, R.E. (1991). Student Team Learning: A Practical Guide to Cooperative Learning. Washington D.C: National Education Association.

Slavin, R.E. (1995). Cooperative Learning: Theory, Research and Practice. Massachusetts: Allyne and Bacon.

Slavin, R.E. (2000). Educational Psychology Theory and Practice. Boston: Allyne \& Bacon

Sprinthall, A.N. (2000). Educational Psychology. New York: McGraw Hill

Wool folk, A. (2004). Educational Psychology. Singapore: Person Education, Inc. 
Table 1. Mean and Standard deviation of marks obtained by experimental group and control group in the subject of General Science in annual examination 2010

\begin{tabular}{|c|c|c|c|}
\hline Group & $\mathrm{N}$ & $\mathrm{X}$ & $\mathrm{SD}$ \\
\hline Experimental & 18 & 53.0 & 19.2 \\
\hline Control & 18 & 50.3 & 13.7 \\
\hline
\end{tabular}

Table 2. Mean and standard deviation of pretest scores of experimental group and control group

\begin{tabular}{|c|c|c|c|}
\hline Group & $\mathrm{N}$ & $\mathrm{X}$ & $\mathrm{SD}$ \\
\hline Experimental & 18 & 11.89 & 2.07 \\
\hline Control & 18 & 11.78 & 2.26 \\
\hline
\end{tabular}

Table 3. Mean and standard deviation of experimental group and control group on posttest

\begin{tabular}{|c|c|c|c|}
\hline Group & $\mathrm{N}$ & $\mathrm{X}$ & SD \\
\hline Experimental & 18 & 27.3 & 1.3 \\
\hline Control & 18 & 21.1 & 2.87 \\
\hline
\end{tabular}

Mean difference: 6.2

Table 4. Mean and standard deviation of pretest and posttest scores of experiment group

\begin{tabular}{|c|c|c|c|}
\hline Test & $\mathrm{N}$ & $\mathrm{X}$ & SD \\
\hline Pretest & 18 & 11.8 & 2.07 \\
\hline Posttest & 18 & 27.3 & 1.3 \\
\hline
\end{tabular}

Mean difference: 15.3

Table 5. Mean and standard deviation of pretest and posttest scores of control group

\begin{tabular}{|c|c|c|c|}
\hline Test & N & X & SD \\
\hline Pretest & 18 & 11.7 & 2.07 \\
\hline Posttest & 18 & 21.1 & 2.87 \\
\hline
\end{tabular}

Mean difference: 9.33

Table 6. Significance of difference between mean pretest scores and mean posttest scores of experimental group

\begin{tabular}{|c|c|c|c|c|c|c|}
\hline Test & $\mathrm{N}$ & $\mathrm{X}$ & $\mathrm{SD}$ & $\mathrm{T}$ & .05 & $\mathrm{p}$ \\
\hline Pretest & 18 & 11.89 & 2.07 & \multirow{2}{*}{51.7} & 2.03 & 5 \\
\cline { 1 - 5 } Posttest & 18 & 27.13 & 1.3 & & & \\
\hline
\end{tabular}

Table 7. Significance of difference between mean pretest scores and mean posttest scores of control group

\begin{tabular}{|c|c|c|c|c|c|c|}
\hline Test & $\mathrm{N}$ & $\mathrm{X}$ & $\mathrm{SD}$ & $\mathrm{t}$ & .05 & $\mathrm{p}$ \\
\cline { 1 - 4 } Pretest & 18 & 11.78 & 2.26 & \multirow{2}{*}{41.8} & \multirow{2}{*}{2.03} & 5 \\
\cline { 1 - 5 } Posttest & 18 & 21.1 & 2.87 & & & \\
\hline
\end{tabular}

Table 8. Significance of difference between mean posttest scores of experimental group and mean posttest score of control group

\begin{tabular}{|l|l|l|l|l|l|l|}
\hline Test & $\mathrm{N}$ & $\mathrm{X}$ & $\mathrm{SD}$ & $\mathrm{t}$ & .05 & $\mathrm{p}$ \\
\hline Pretest & 18 & 27.03 & 1.3 & 8.07 & 2.03 & 5 \\
\hline Posttest & 18 & 21.10 & 2.8 & & & \\
\hline
\end{tabular}

